\title{
Avoiding Diagnostic Lens Fogging During the COVID-19 Era: Options to Consider [Response To Letter]
}

This article was published in the following Dove Press journal: Clinical Ophthalmology

\author{
David Pérez González (D) \\ Anat Loewenstein' \\ Dan D Gaton ${ }^{2}$
}

'Department of Ophthalmology, Tel Aviv Sourasky Medical Center, Sackler Faculty of Medicine, Tel Aviv, Israel; ${ }^{2}$ Department of Ophthalmology, Rabin Medical Center, Sackler Faculty of Medicine, Tel Aviv, Israe
Correspondence: David Pérez González Department of Ophthalmology,

Tel Aviv Sourasky Medical Center, Sackler Faculty of Medicine, Weizmann Street \#6, Tel Aviv 6423906, Israel

Tel +972-058-767-847।

Email davidperezgonzalez90@gmail.com

\section{Dear editor}

We would like to thank Gorgoli et al ${ }^{1}$ for their interest in our article. ${ }^{2}$ Our suggested method is certainly not the only one, and the more the ophthalmic community will have, the better.

We share the concerns of what Gorgoli et al raised, where touching the upper part of the mask may expose us to more significant contamination, either by contact with eye secretions or by touching the mask's infected area. However, as we mentioned in our article, and as is also widely expressed in recent literature, infection by ocular secretions has not been fully demonstrated. ${ }^{3}$ Also, there is no evidence in the literature that touching the mask has any negative outcome neither for the ophthalmologist nor for the patient. The gloves are highly suggested in our method and with a little practice, one can hold the mask and not touch the diagnostic lens at all times until the gloves are changed, therefore with less risk of contaminating the medical equipment.

A recent study was conducted at a dedicated SARS-CoV-2 outbreak center in Singapore in airborne infection isolation rooms. Personal Protective Equipment (PPE) samples from physicians exiting the patient rooms were collected, and interestingly enough, there were no positive samples from the masks surfaces. ${ }^{4}$ Albeit the front part of the mask should be considered infected as a general precaution, further studies are required to corroborate these preliminary data, primarily in the current real-life pandemic situation.

The World Health Organization's advice ${ }^{5}$ mentioned by Gorgoli et al focuses on general practices, and the recommendations issued are intended mainly for the general public and less for the experienced professional medical staff.

Regarding the idea of using adhesive medical tape on the upper part of the mask is, of course, a possibility, but one has to take into consideration that many patients are not comfortable with the adhesive medical tape fixed to their face and actually may refuse to cooperate, not to mention that such a routine maneuver requires supplement staff assigned for this role, which may be a great challenge, especially in public hospitals, with a high demand for care and, in many regions, where the health care system is over-saturated by the current crisis.

Finally, we would like to point out that this global pandemic situation is an excellent opportunity to raise, promote, and debate scientific ideas. Science is 
a cooperative enterprise, and we are glad to work together towards the common good for our society.

\section{Disclosure}

The authors report no conflicts of interest in this communication.

\section{References}

1. Gorgoli K, Benekos K, Katsanos A. Avoiding diagnostic lens fogging during the COVID-19 Era: options to consider [Letter]. Clin Ophthalmol. 2021;15:211-212. doi:10.2147/OPTH.S301790
2. Pérez González D, Loewenstein A, Gaton DD. Avoiding diagnostic lens fogging during the COVID-19 Era. Clin Ophthalmol. 2020;14:4507-4509. doi:10.2147/OPTH.S286736

3. Xia J, Tong J, Liu M, Shen Y, Guo D. Evaluation of coronavirus in tears and conjunctival secretions of patients with SARS-CoV-2 infection. J Med Virol. 2021;Volume 15(6):589-594. doi:10.2147/ OPTH.S301790

4. Ong SWX, Tan YK, Chia PY, et al. Air, surface environmental, and personal protective equipment contamination by severe acute respiratory syndrome coronavirus 2 (SARS-CoV-2) from a symptomatic patient. JAMA. 2020;323(16):1610. doi:10.1001/jama.2020.3227

5. WHO. World Health Organization (WHO) [homepage on the internet]; 2020. Available from: https://www.who.int/news-room /q-a-detail/coronavirus-disease-covid-19-masks. Accessed January 17, 2021.

Dove Medical Press encourages responsible, free and frank academic debate. The content of the Clinical Ophthalmology 'letters to the editor' section does not necessarily represent the views of Dove Medical Press, its officers, agents, employees, related entities or the Clinical Ophthalmology editors. While all reasonable steps have been taken to confirm the content of each letter, Dove Medical Press accepts no liability in respect of the content of any letter, nor is it responsible for the content and accuracy of any letter to the editor

\section{Publish your work in this journal}

Clinical Ophthalmology is an international, peer-reviewed journal covering all subspecialties within ophthalmology. Key topics include: Optometry; Visual science; Pharmacology and drug therapy in eye diseases; Basic Sciences; Primary and Secondary eye care; Patient Safety and Quality of Care Improvements. This journal is indexed on PubMed

Submit your manuscript here: https://www.dovepress.com/clinical-ophthalmology-journal
Central and CAS, and is the official journal of The Society of Clinical Ophthalmology (SCO). The manuscript management system is completely online and includes a very quick and fair peer-review system, which is all easy to use. Visit http://www.dovepress.com/ testimonials.php to read real quotes from published authors. 